\title{
Microzavaljus, a second extinct genus of pleasing fungus beetles (Coleoptera: Erotylidae) from Bitterfeld Amber
}

\author{
Microzavaljus, второй вымерший род жкуков-грибовиков \\ (Erotylidae: Coleoptera) из саксонского янтаря
}

\author{
G.Yu. Lyubarsky ${ }^{1}$, E.E. Perkovsky ${ }^{2}$ \\ Г.Ю. Аюбарский ${ }^{1}$, Е.Э. Перковский
}

\footnotetext{
1 Zoological Museum, Moscow Lomonosov State University, Bol'shaya Nikitskaya 2, Moscow 125009, Russia. E-mail: 1georgy@rambler.ru 1 Зоологический музей, Московский государственный университет им. М.В. Ломоносова, Большая Никитская ул., 2, Москва 125009 , Россия.

2 Schmalhausen Institute of Zoology, National Academy of Sciences of Ukraine, Bogdan Khmielnitsky str. 15, Kiev 01601, Ukraine. E-mail: perkovsk@gmail.com
}

KEY WORDS: Erotylidae, Xenoscelinae, Microzavaljus, taxonomy, Late Eocene, Bitterfeld amber.

КЛЮЧЕВЫЕ СЛОВА: Erotylidae, Хenoscelinae, Microzavaljus, таксономия, поздний эоцен, саксонский янтарь.

ABSTRACT. Based on a fossil specimen from the Late Eocene Bitterfeld amber, Microzavaljus saxonicum gen.n., sp.n., is described. The new genus belongs to subfamily Xenoscelinae Ganglbauer, 1899 (Coleoptera: Erotylidae). The new genus is similar to the extinct genus Warnis Lyubarsky, Perkovsky et Alekseev, 2016, differing in submetacoxal lines absent, and similar to extant genus Zavaljus Reitter, 1880, differing in body size, supraocular lines present, and pronotal sides smooth, not serrate. Eocene fauna of Xenoscelinae is now composed of 4 genera: Xenochimatium Lyubarsky et Perkovsky, 2012 from Rovno amber, Xenophagus Lyubarsky et Perkovsky, 2017 and Warnis Lyubarsky et al., 2016 from Baltic amber, and the new genus from Bitterfeld amber.

РЕЗЮМЕ. Из позднеэоценового саксонского янтаря описан новый род жуков Microzavaljus saxonicum gen.n., sp.n. из подсемейства Xenoscelinae Ganglbauer, 1899 (Coleoptera: Erotylidae). Новый род во многом схож с родом Warnis Lyubarsky, Perkovsky et Alekseev, 2016 из балтийского янтаря, отличается от него отсутствием субметакоксальных линий. Сходен с современным родом Zavaljus Reitter, 1880, отличается размером, наличием супраокулярных линий, отсутствием слабой зазубренности на боковом крае переднеспинки. Эоценовая фауна Xenoscelinae представлена 4 родами: Xenochimatium Lyubarsky et Perkovsky, 2012 из ровенского янтаря, Xenophagus Lyubarsky, Perkovsky, 2017 и Warnis Lyubarsky et al., 2016 из балтийского янтаря, и новым родом из саксонского янтаря.

\section{Introduction}

A study of the collection of Christel and Hans Werner Hoffeins $(\mathrm{CCHH})$ revealed a new genus of beetles. The new genus belongs to the family Erotylidae, since it has the following characters: epimera long, reaching the 3 rd abdominal segment; $1^{\text {st }}$ segment of abdomen relatively short, about 1.3 times longer than $2^{\text {nd }}$; punctation of elytra situated in rows. The family Erotylidae is a group of small and medium size beetles with about 3500 described species in almost 300 genera, represented in all continents except Antarctica [Wegrzynowicz, 2002, 2007; Leschen, 2003; Leschen et al., 2010]. The family belongs with the superfamily Cucujoidea.

The phylogenetic position of the Erotylidae is described in Robertson et al. [2004, 2015]. The classification of the family was most recently revised by Leschen [Leschen, Węgrzynowicz, 1998; Leschen, 2003]. The family Erotylidae includes six subfamilies (Xenoscelinae, Pharaxonothinae, Loberinae, Languriinae, Cryptophilinae, and Erotylinae). The family has not been sufficiently studied, many subfamilies are identified as paraphyletic, generic and species diagnostics of many subfamilies have not been insufficiently studied.

\section{Palaeontological data}

Palaeontological data concerning the family Erotylidae were reported by Wegrzynowicz [2002]. There are quite a few findings of the Xenoscelinae Ganglbauer, 1899 subfamily. Recent studies discovered samples of

How to cite this article: Lyubarsky G.Yu., Perkovsky E.E. 2018. Microzavaljus, a second extinct genus of pleasing fungus beetles (Coleoptera: Erotylidae) from Bitterfeld Amber // Russian Entomol. J. Vol.27. No.3. P.271-276. doi: 10.15298/rusentj.27.3.05 
the Xenoscelinae dating from the Cretaceous period [Kirejtshuk, Azar, 2013]. The specimen found had body size at least $2.0 \mathrm{~mm}$, diffusely punctured and finely pubescent elytra, 4-segmented loose antennal club and widely lobed tarsomeres 1-3. Recently described erotylids from Late Eocene Baltic, Bitterfeld and Rovno ambers [Alekseev 2014, 2017; Lyubarsky, Perkovsky 2012, 2017a, 2017b; Lyubarsky et al. 2016] were placed in Erotylinae Latreille, 1802 (Triplax contienensis Alekseev, 2014), Languriinae Crotch, 1873 (Serramorphus rasnitsyni Lyubarsky et Perkovsky, 2017), and Xenoscelinae Ganglbauer, 1899 (Xenochimatium rovnense Lyubarsky et Perkovsky, 2012; Warnis tvanksticus Ly- ubarsky, Perkovsky et Alekseev, 2016; Xenophagus popovi Lyubarsky et Perkovsky, 2017), and for the first time Pharaxonothinae Crowson, 1952 from Baltic amber, Cycadophila mumia Alekseev, 2017. The new genus belongs to Xenoscelinae, which makes Xenoscelinae the most diverse subfamily in the Late Eocene ambers. In the three erotylid faunas from Late Eocene ambers no common genera have been found so far.

Photographs were taken at the Schmalhausen Institute of Zoology (Kiev, SIZK) using the microscope Leica MZ 16 and in Paleontological Institute (Moscow, PIN) using a Leica M 165 microscope equipped with a Leica DFC 425 camera.
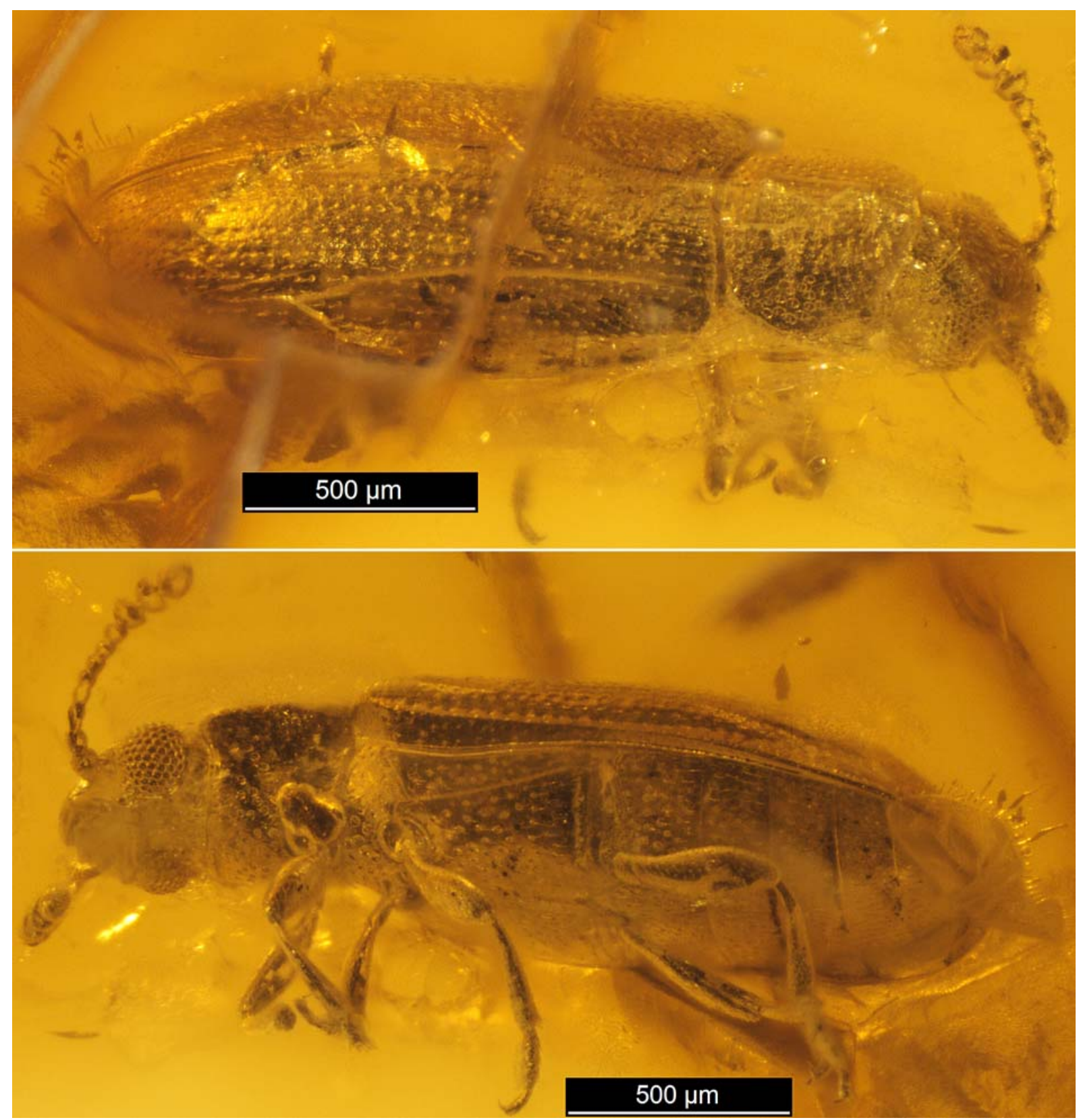

Figs 1-2. Holotype Microzavaljus saxonicum sp.n., habitus (photo): 1 - dorsal view; 2 - ventral view. Рис. 1-2. Голотип Microzavaljus saxonicum sp.n., общий вид (фотография): 1 - сверху; 2 - снизу. 


\section{Taxonomy}

\section{Order Coleoptera}

Superfamily Cucujoidea Latreille, 1802

Family Erotylidae Latreille, 1802

Subfamily Xenoscelinae Ganglbauer, 1899

\section{Microzavaljus gen.nov.}

Type species: Microzavaljus saxonicum.

DESCRIPTION. Body elongated, narrow. Antennae with 11 antennomeres and a 3-segmented club. Frontoclypeal suture absent. Antennal insertion hidden in dorsal view. Labial palpus 2-segmented, second segment of palpus much longer than first segment. Supraocular line present.

Pronotum nearly parallel-sided, slightly narrowed in posterior third of its length. Pronotum without callosities in anterior angles. Posterior edge with medial lobe. Pronotal puncturation confused. Basal pronotal pits absent, basal groove absent. Scutellum normal in size, trapezoidal, with small punctures, width of scutellum less than length of eye. Procoxal process between procoxal cavity narrower than width of procoxa. Procoxal cavity internally closed and externally open. Width of mesoventral process narrower than mesocoxa. Submesocoxal lines absent. Metacoxal cavity narrowed. Longitudinal line in metasternum present.

Legs slender, tibia without spurs in apex. Tarsi 5-5-5, longest tarsomere 5 with long serrated claw. Length of tarsomere 1 greater than tarsomere 2. Tarsomeres without lobes, with long setae from below.
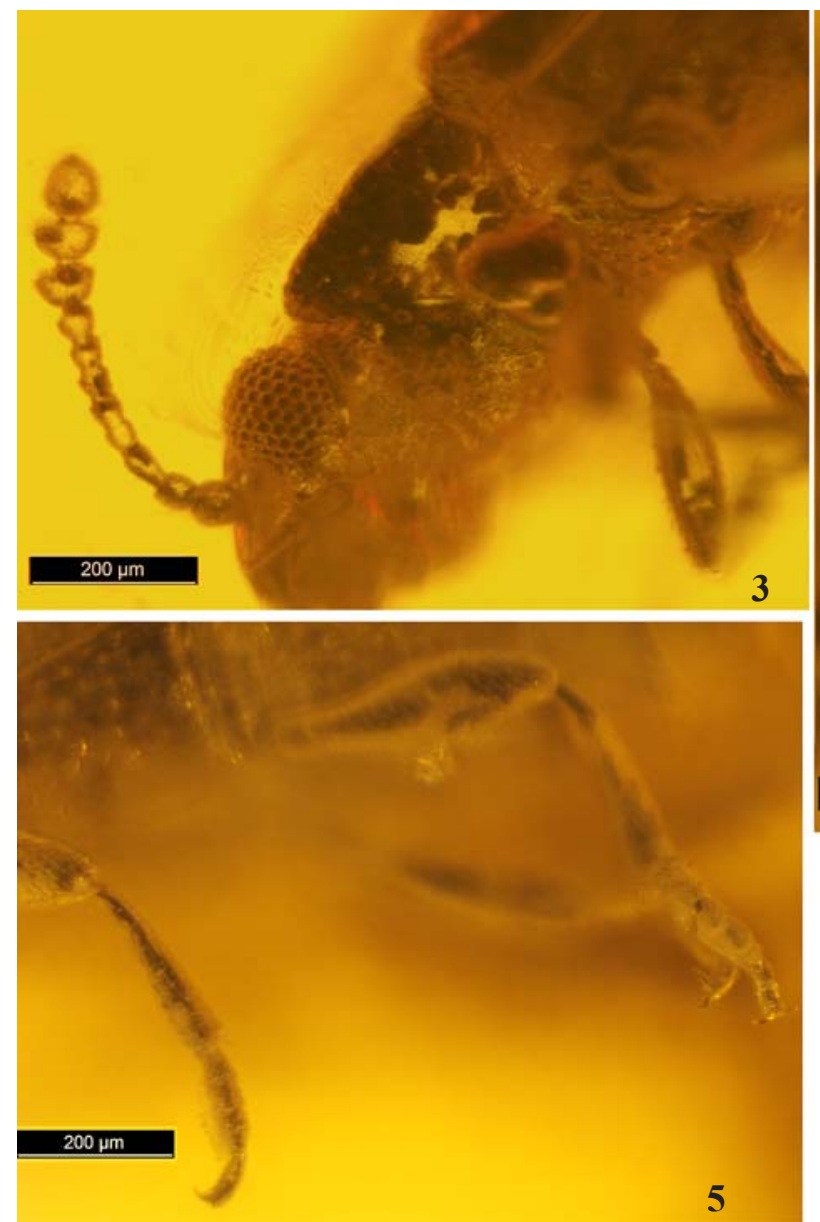

Elytral length $2.2 x$ that of width. Elytra completely covering the abdomen. Epimere almost complete, reaching $3^{\text {rd }}$ segment of the abdomen. Wings present.

Abdomen with 5 segments; segment 1 less than twice as long as the next, only about 1.3 times longer. Submetacoxal lines absent.

DIAGNOSIS. Pronotal pits absent; pronotum parallelsided; submesocoxal lines absent; submesocoxal lines absent; length of tarsomere 1 greater than tarsomere 2 .

ETYMOLOGY. The genus name is grammatically masculine. It is compounded from micro- and the name of genus, Zavaljus.

\section{Microzavaljus saxonicum sp.n.}

Figs $1-6$.

MATERIAL. Holotype: 1223-1, in collection of Christel and Hans Werner Hoffeins (Hamburg), Bitterfeld amber. Type will be deposited at the amber collection of Senckenberg Deutsches Entomologisches Institut, Müncheberg (SDEI), Germany. Collection code: $\mathrm{CCHH}$.

DESCRIPTION. Body parallel-sided, with white hairs, length of body $2.1 \mathrm{~mm}$, maximal width $0.7 \mathrm{~mm}$ (Fig. 1).

Head with hemispherical eyes. Eyes relatively large, length of eye equal to half length of head. Facets medium size, approximately equal to diameter of puncture. Punctuation of head: punctures medium in size, distance between neighboring punctures equal to or a bit greater than one diameter of puncture. Frons weakly convex, punctuate. Antennae relatively short, not reaching beyond hind edge of pronotum (Fig. 2). Antennal club asymmetrical, slightly

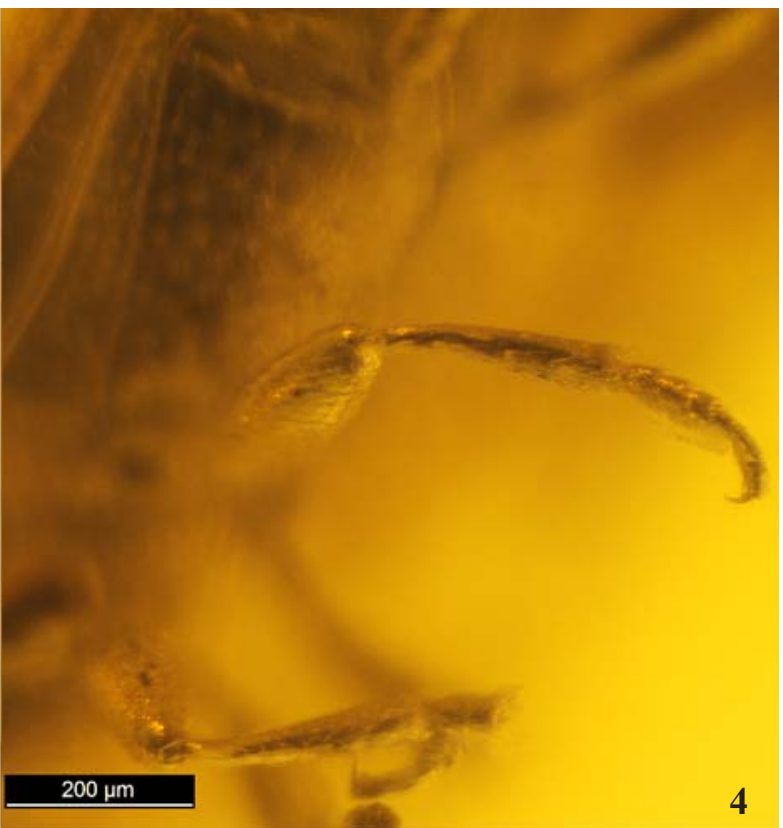

Figs 3-5. Holotype Microzavaljus saxonicum sp.n. (photo): 3 - head and prothorax, ventral view; 4 - mesotarsus; 5 - mesoand metatarsus.

Рис. 3-5. Голотип Microzavaljus saxonicum sp.n.: (фотография): 3 - голова и переднегрудь снизу; 4 - средняя лапка; 5 - средняя и задняя лапки. 


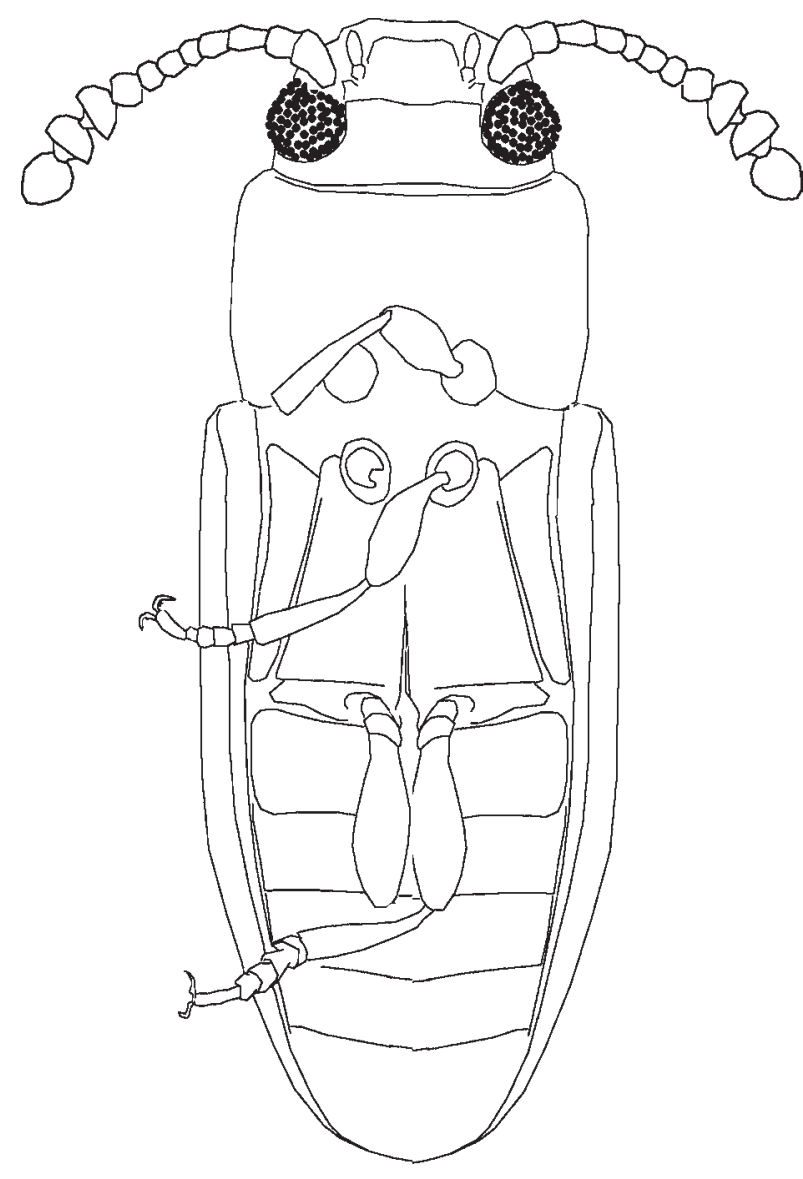

Fig. 6. Holotype Microzavaljus saxonicum sp.n., ventral view, drawing.

Рис. 6. Голотип Microzavaljus saxonicum sp.n., снизу, реконструкция.

flattened. $1^{\text {st }}$ antennomere longest, elongated (Figs 3, 6). $3^{\text {rd }}$ antennomere longest of the segments of flagellum, and other segments of flagellum approximately equal, slightly elongate. $9^{\text {th }}$ and $10^{\text {th }}$ antennomeres conical, transverse, twice as wide as flagellum. Terminal antennomere rounded. Antennal furrows absent.

Pronotum almost parallel-sided, without callosity and teeth, length of pronotum equal to 0.8 of its width, length of pronotum equal to 0.3 length of elytra. Punctation moderately strong, distance between neighboring punctures equal to one diameter of puncture. Anterior margin slightly convex. Lateral margins without cants. Posterior margin with basal lobe, without basal depression, basal pits absent. Posterior angles acutangular.

Prosternum in front of procoxae long. Distance between metacoxae much less than diameter of metacoxa. Pre-, meso, and metasternum strongly and not densely punctated (Fig. 2). Legs slender, tibia not dilated apically (Figs 4-5). Tarsomeres slightly elongated. Tarsomeres $1-4$ about equal in length $\left(1^{\text {st }}\right.$ tarsomere a little longer than the others), the longest being tarsomere 5, which is shorter than all other taken together (Figs 4-5).

Scutellum transverse, its width 1.5 times greater its length, width equal to width of eye.

Punctuation of elytra: punctures medium in size, arranged in rows, distance between neighboring punctures
1-1.5 diameter of puncture. Punctures in rows include 9 rows of larger dots, and intermediate rows of weaker points between them. Elytra covered with short light hairs arranged in rows. Hairs only slightly raised and a little overlaying each other. Surface of the elytra shagreenate.

Ventrites weakly pubescent, irregularly punctured.

ETYMOLOGY. The species is named saxonicum, because it was found in Bitterfeld amber (Saxony-Anhalt).

REMARKS. The specimens considered here were assigned to the subfamily Xenoscelinae based on a combination of the following visible external morphological characters: antennal insertion hidden in dorsal view; supraocular line present; pronotum parallel-sided; anterior angles of pronotum poorly developed; pronotal pits absent (present in Protoloberus and Zavaljus); internal closure of procoxal cavity closed (open in Loberonotha); external closure of procoxal cavity open; width of mesoventral process narrower than mesocoxa; submesocoxal lines absent; length of tarsomere 1 greater than tarsomere 2; tarsomere 3 not lobed, tarsomere 4 reduced as in all xenoscelines except Zavaljus and Microzavaljus and exposed in ventral view; elytral punctation striate. Thus, the characters of the new genus fit this diagnosis of subfamily Xenoscelinae.

Subfamily Xenoscelinae includes the following genera: Loberonotha (1 species; New Zealand), Macrophagus (1 species; Asia and Europe), Othniocryptus (1 species; Neotropical), Protoloberus (1 species; Australia), Xenocryptus (2 species; Africa and Australia), Xenoscelis (1 species; Mediterranean), Zavaljus (1 species; Northern Europe), and extinct monotypic genera Xenohimatium from the Late Eocene Rovno amber (Ukraine), Warnis and Xenophagus from Late Eocene Baltic amber.

\section{Key to genera of Subfamily Xenoscelinae}

1. Submetacoxal lines present. Tarsi without lobes ........ 2

- Submetacoxal lines absent. Tarsi with or without lobes.

. Sides of pronotum not parallel, pronotum widest in middle. Elytra blue-green, covered by rows of punctures. Ovipositor dilated, with a sclerotised, hook-like gonostyle with basal setae. Recent, Central Africa..... Arrowcryptus Leschen et Wegrzynowicz, 2008

- Sides of pronotum parallel. Elytra dark or testaceus. Ovipositor not dilated. Extinct, Baltic amber. ............ 3

3. Elytral puncturation confused. ......................................

- Elytra covered by rows of punctures Warnis Lyubarsky, Perkovsky et Alekseev, 2016

4. Pronotum completely parallel-sided ............................... 5

- Pronotum widest within apical one third .................... 6

5. Lateral carina on elytra present. Pronotum considerably elongated. Recent, Mediterranean ..... Xenoscelis Wollaston, 1864

- Lateral carina on elytra absent. Pronotum transversal. Extinct, Baltic amber.

Xenohimatium Lyubarsky et Perkovsky, 2012

6. Elytral punctuation confused ..................................... 7

- Elytral punctuation arranged in rows .......................... 9

7. Epipleura short, widened to level of metathorax. Recent, New Zealand

Loberonotha Sen Gupta et Crowson, 1969 Epipleura long, widened to $3^{\text {rd }}$ ventrite or elytral tips. Tarsi with lobes.... 
8. Unicolorous, light brown. Recent, Central and Eastern Europe, Caucasus, Central Asia

Macrophagus Motschulsky, 1875

- Body with two colors, light background with dark mottles. Recent, Central America ..... Othniocryptus Sharp, 1900

9. Tarsi seem 4-segmented, because of reduced tarsomere 4. Supraocular line present. Recent, Australia....

Protoloberus Leschen, 2003

- Tarsi 5-segmented, tarsomere 4 not reduced ............. 10

10. Antennae long, reaching beyond posterior edge of pronotum. Length 4.2-4.8 mm. Pronotal sides slightly crenulate. Supraocular line absent. Recent, Northern and Eastern Europe. Zavaljus Reitter, 1880

- Antenna short, reaching only middle of pronotum. .. 11

11. Legs short, tibia dilated, tarsomeres a little flattened, weakly lobed below. Length $4.5 \mathrm{~mm}$. Recent, Australia, South Africa ....................... Xenocryptus Arrow, 1929

- Legs normal in length, tibia slender, tarsomeres not flattened, not lobed. Pronotal sides smooth. Supraocular line present. Length $2.1 \mathrm{~mm}$. Extinct, Bitterfeld amber .......

Microzavaljus gen.n.

\section{Discussion}

Wolfe et al. [2016] demonstrated that the source of Bitterfeld amber had much lower paleolatitude than the source of coeval Baltic amber. Our previous studies of ants [Perkovsky, 2011,2016], corethrellids [Baranov et al., 2016], phalacrids [Lyubarsky, Perkovsky, 2016] and erotylids [Lyubarsky, Perkovsky, 2017a] demonstrated that the share of thermophilous elements in Bitterfeld amber is much higher than in the Baltic one. Tropical Ceratopogoninae are more common in Bitterfeld amber than in Baltic amber as well [Perkovsky, 2017]. The finding of a new genus of the largely extra-holarctic subfamily Xenoscelinae in Bitterfeld amber is a further evidence of the relative abundance of the thermophilic elements in Bitterfeld amber.

The new genus belongs to Xenoscelinae, which makes Xenoscelinae the most diverse subfamily in the Late Eocene ambers. While some Xenoscelinae are strictly phytophagous on living tissues, other xenoscelines are associated with decaying plant material and may be saprophagous, mycophagous (on spores and hyphae of microfungi), or pollen feeding; the transition to association with dead wood in Zavaljus is derived from phytophagy [Leshen, Buckley, 2007]. So far, no common erotylid genera have been found in the three Late Eocene amber faunas. The fact that none of the four genera of the Eocene Xenoscelinae is known from more than one amber fauna is an evidence of geographically different sources of Bitterfeld, Baltic and Rovno amber.

ACKNOWLEDGMENTS. We are grateful to Christel and Hans Werner Hoffeins (Hamburg, Germany) for providing the material, and to Vitaly Nazarenko (SIZK) and Alex Rasnitsyn (PIN) for help with photos. The work of the first author has been supported by the grant AAAA-A16116021660077-3.

\section{References}

Alekseev V.I. 2014. A new species of Triplax Herbst (Coleoptera: Erotylidae) from Bitterfeld amber // Baltic Journal of Coleopterology. Vol.14. No.2. P.171-177.

Alekseev V.I., Bukejs A. 2017. First fossil representatives of Pharaxonothinae Crowson (Coleoptera: Erotylidae): indirect evidence for cycads existence in Baltic amber forest // Zootaxa. Vol.4337. No.3. P.413-422. doi: 10.11646/zootaxa.4337.3.6.

Baranov V. A., Kvifte G. M., Perkovsky E. E. 2016. Two new species of fossil Corethrella Coquillett from Late Eocene Rovno amber, with a species-level phylogeny for the family based on morphological traits (Diptera: Corethrellidae) // Systematic Entomology. Vol.41. No.3. P. 531-540.

Kirejtshuk A.G., Azar D. 2013. Current knowledge of Coleoptera (Insecta) from the Lower Cretaceous Lebanese amber and taxonomical notes for some Mesozoic groups // Terrestrial Arthropod Reviews. Vol.6. No.1-2. P.103-134.

Leschen R.A.B. 2003. Erotylidae (Insecta: Coleoptera: Cucujoidea): Phylogeny and review // Fauna of New Zealand. Vol.47. P.1-108.

Leschen R.A.B., Buckley T.R. 2007. Multistate Characters and Diet Shifts: Evolution of Erotylidae (Coleoptera) // Systematic biology. Vol.56. P.97-112.

Leschen R.A.B., Węgrzynowicz P. 1998. Generic Catalogue and Taxonomic Status of Languriidae (Cucujoidea) // Annales Zoologici (Warszawa). Vol.48. Nos 3-4. P.221-243.

Leschen R.A.B., Skelley P.E., McHugh J.V. 2010. 10.7. Erotylidae Leach, 1815. In: Leschen, R.A.B., Beutel, R.G., Lawrence, J.F.(Eds.), Coleoptera, beetles. Vol.2: Morphology and systematics (Elateroidea, Bostrichiformia, Cucujiformia partim) // Kristensen N.P., Beutel R.G. (eds.). Handbook of zoology. A natural history of the phyla of the animal kingdom. Volume IV. Arthropoda: Insecta. Part 38. Berlin, New York: Walter de Gruyter. P.311-319.

Lyubarsky G.Yu., Perkovsky E.E. 2012. A new genus of Erotylidae from Eocene amber (Coleoptera: Clavicornia) // Russian Entomological Journal. Vol.21. No.1. Pp.35-38.

Lyubarsky G.Yu., Perkovsky E.E. 2016. A new genus, Neolitochropus (Coleoptera: Cucujoidea: Phalacridae), from the Upper Eocene Bitterfeld amber // Russian Entomological Journal. Vol.25. No.3. P.249-253.

Lyubarsky G.Yu., Perkovsky E.E. 2017a. Serramorphus, a new genus of Erotylidae from Eocene amber (Coleoptera: Clavicornia) from Late Eocene Bitterfeldian Amber // Russian Entomological Journal. Vol.26. No.1. P.37-40.

Lyubarsky G.Yu., Perkovsky E.E. 2017b. Xenophagus, a new genus of pleasing fungus beetles (Coleoptera: Erotylidae) from Baltic amber // Russian Entomological Journal. Vol.26. No.2. Pp.147-150.

Lyubarsky G.Yu., Perkovsky E.E., Alekseev V.I. 2016. The First Record of the Subfamily Xenoscelinae (Coleoptera, Erotylidae) from the Baltic Amber // Paleontological Journal. Vol.50. No.9. P. 963-969.

Perkovsky E.E. 2011. Syninclusions of the Eocene winter ant Prenolepis henshei (Hymenoptera: Formicidae) and Germaraphis aphids (Hemiptera: Eriosomatidae) in Late Eocene Baltic and Rovno amber: some implications // Russian Entomological Journal. Vol.20. No.3. P.303-313.

Perkovsky E.E. 2016. Tropical and Holarctic ants in Late Eocene ambers// Vestnik Zoologii. Vol.50. No.2. P.111-122.

Perkovsky E.E. 2017. Comparison of biting midges of the Early Eocene Cambay amber (India) and Late Eocene European Ambers supports the independent origin of European ambers // Vestnik Zoologii Vol.51. No.4. P.275-284.

Robertson J.A., McHugh J.V., Whiting M.F. 2004. A molecular phylogenetic analysis of the pleasing fungus beetles (Coleoptera: Erotylidae): evolution of colour patterns, gregariousness and mycophagy // Systematic Entomology. Vol.29. P.173-187.

Robertson J.A., Slipinski A., Moulton M., Shockley F.W., Giorgi A., Lord N.P., McKenna D.D., Tomaszewska W., Forrester J., Miller K.B., Whiting M.F., McHugh J.V. 2015. Phylogeny and 
classification of Cucujoidea and the recognition of a new superfamily Coccinelloidea (Coleoptera: Cucujiformia) // Systematic Entomology. Vol.40. P.745-778.

Węgrzynowicz P. 2002. Morphology, phylogeny and classification of the family Erotylidae based on adult characters (Coleoptera: Cucujoidea) // Genus. Vol.13. No.4. P.435-504.

Węgrzynowicz P. 2007. Family Erotylidae Latreille, 1802 // Löbl I.,
Smetana A. (eds.). Catalogue of Palaearctic Coleoptera. Vol.4. Stenstrup: Apollo Books. 935 pp.

Wolfe A.P., McKellar R.C., Tappert R., Sodhi R.N.S., Muehlenbachs K. 2016. Bitterfeld amber is not Baltic amber: Three geochemical tests and further constraints on the botanical affinities of succinite // Review of Palaeobotany and Palynology. Vol.225. P.21-32. doi: 10.1016/j.revpalbo.2015.11.002. 